\title{
Enterobacter gergoviae sp. nov.: a New Species of Enterobacteriaceae Found in Clinical Specimens and the Environment
}

\author{
DON J. BRENNER, ${ }^{1}$ C. RICHARD, ${ }^{2 *}$ ARNOLD G. STEIGERWALT, ${ }^{3}$ MARY A. ASBURY, ${ }^{3}$ AND \\ MANLEY MANDEL ${ }^{3}$
}

Enteric Section, Center for Disease Control, Atlanta, Georgia 30333; ${ }^{1}$ Service des Enterobacteries, Institut Pasteur, F.75724 Paris, Cedex 15, France; ${ }^{2}$ and University of Texas System Cancer Center, M.D. Anderson Hospital and Tumor Institute, Houston, Texas $77030^{3}$

\begin{abstract}
The name Enterobacter gergoviae sp. nov. is proposed for a group of organisms isolated from various clinical sources in France, Africa, and the United States and from environmental sources. $E$. gergoviae deoxyribonucleic acid contains $60 \%$ guanine plus cytosine. Deoxyribonucleic acid relatedness studies showed $E$. gergoviae strains to be very highly related, as is characteristic of strains of a single species. The biochemical profiles of $E$. gergoviae strains were extremely similar. Phenotypically, $E$. gergoviae belongs to the family Enterobacteriaceae and is most similar to Enterobacter aerogenes. E. gergoviae is distinguishable from $E$. aerogenes by its positive urea reaction and negative reactions for $\mathrm{KCN}$, sorbitol, mucate, and gelatinase. Strain CIP 76.01 (= ATCC $33028=$ CDC 60477 ) is the type strain of this new species.
\end{abstract}

Richard et al. (8) described a new group of organisms that was biochemically most similar to Enterobacter aerogenes. The 30 strains comprising this group were distinguishable from $E$. aerogenes by their positive urea reaction and negative reactions for $\mathrm{KCN}$, sorbitol, mucate, gelatinase, $\beta$-xylosidase, and $\alpha$-methylglucoside. These strains were isolated from a variety of clinical and environmental sources in France and Africa. Ten strains isolated from urines during a hospital outbreak were multiply drug resistant.

Since the initial description of this group (8), 40 additional strains were received at the Center for Disease Control, and 11 additional strains were received at the Institut Pasteur. We now report characterization of this group by biochemical tests, antibiotic susceptibility, and deoxyribonucleic acid (DNA) relatedness. On the basis of these data, we propose the name Enterobacter gergoviae sp. nov. for these organisms and designate strain CIP 76.01 (= Center for Disease Control [CDC] 604-77 = American Type Culture Collection [ATCC] 33028) as the type strain.

\section{MATERIALS AND METHODS}

The strains used in this study are listed in Table 1. Biochemical tests were done essentially as previously described by Edwards and Ewing (5) and Richard et al. (7). Antibiotic susceptibility was assayed with the standardized disk method of Bauer et al. (1).

The preparation, isolation, and purification of labeled and unlabeled DNA, the method used for DNA reassociation, and the method used to separate single- and double-stranded DNA on hydroxyapatite have been described elsewhere (3).

Guanine plus cytosine $(\mathrm{G}+\mathrm{C})$ composition was determined by $\mathrm{CsCl}$ buoyant density ultracentrifugation (6). Samples were analyzed twice in the presence of reference DNA from phage $2 \mathrm{C}$ of density $1.742 \mathrm{~g} / \mathrm{cm}^{3}$, with reference to DNA from Escherichia coli K-12 taken to be $1.710 \mathrm{~g} / \mathrm{cm}^{3}$.

\section{RESULTS AND DISCUSSION}

Biochemical tests. The biochemical reactions of 81 strains of $E$. gergoviae are presented in Table 2. Thus far, test results have shown these organisms to be homogenous biochemically. The only test in which $90 \%$ or more of the strains failed to give a similar ( + or - ) reaction within $48 \mathrm{~h}$ was acid from lactose. In this test, $58 \%$ of the strains were positive within $48 \mathrm{~h}$, and an additional $40 \%$ gave delayed positive reactions ( 3 to 7 days).

$E$. gergoviae is a gram-negative, oxidase-negative, nitrate-positive, fermentative, rod-shaped organism that is peritrichous when motile. As such, it conforms to the definition of Enterobac. teriaceae.

The biochemical profile of $E$. gergoviae is most similar to those of Enterobacter species. $E$. gergoviae is perhaps most similar to $E$. aerogenes, but these two species can be separated by their reactions in tests for $\mathrm{KCN}$, sorbitol, mucate, and urease (Table 3). The tests of use in differentiating $E$. gergoviae from other species of Enterobacter, Klebsiella pneumoniae, and Hafnia alvei (Enterobacter hafniae) are shown in Table 3. 
TABLE 1. Bacterial strains used in this study

\begin{tabular}{llll}
\hline \multicolumn{1}{c}{ Strain } & & & Source and history \\
\hline Edwardsiella tarda & $3592-64$ & CDC & \\
Enterobacter aerogenes & $1627-66$ & CDC & \\
Enterobacter agglomerans & $2780-70$ & CDC & \\
Enterobacter agglomerans & $1429-71$ & CDC & \\
Enterobacter agglomerans & $1645-71$ & CDC & \\
Enterobacter agglomerans & $3482-71$ & CDC & \\
Enterobacter agglomerans & $4388-71$ & CDC & \\
Enterobacter agglomerans & $5378-71$ & CDC & \\
Enterobacter cloacae & $1347-71$ & CDC
\end{tabular}

Enterobacter gergoviae Enterobacter gergoviae Enterobacter gergoviae Enterobacter gergoviae Enterobacter gergoviae Enterobacter gergoviae Enterobacter gergoviae Enterobacter gergoviae Enterobacter gergoviae Enterobacter gergoviae Enterobacter gergoviae Enterobacter gergoviae Enterobacter gergoviae Enterobacter gergoviae Enterobacter gergoviae Enterobacter gergoviae Enterobacter gergoviae Enterobacter gergoviae Enterobacter gergoviae Enterobacter gergoviae Enterobacter gergoviae Enterobacter gergoviae Enterobacter gergoviae Enterobacter gergoviae Enterobacter gergoviae Enterobacter gergoviae Enterobacter gergoviae Enterobacter gergoviae Enterobacter gergoviae Enterobacter gergoviae Enterobacter gergoviae Enterobacter gergoviae Enterobacter gergoviae Enterobacter gergoviae Enterobacter gergoviae Enterobacter gergoviae Enterobacter gergoviae Enterobacter gergoviae Enterobacter gergoviae Enterobacter gergoviae Enterobacter gergoviae Enterobacter gergoviae Enterobacter gergoviae Enterobacter gergoviae Enterobacter gergoviae Enterobacter gergoviae Enterobacter gergoviae Enterobacter gergoviae Enterobacter gergoviae Enterobacter gergoviae

\author{
76.01 (CDC 604-77) \\ 76.02 (CDC 605-77) \\ 1/77 (CDC 606-77) \\ 12/76 (CDC 607-77) \\ 11/76 (CDC 608-77) \\ 5/76 (CDC 609-77) \\ 20/75 (CDC 610-77) \\ 2656-76 \\ 2787-76 \\ 2863-76 \\ $3782-76$ \\ $3866-76$ \\ 569-77 \\ 1004-77 \\ 1007-77 \\ 1061-77 \\ 1062-77 \\ 1063-77 \\ 1064-77 \\ 1065-77 \\ 1067-77 \\ 1068-77 \\ 1069-77 \\ 1070-77 \\ 1071-77 \\ 1072-77 \\ 1073-77 \\ 1404-77 \\ 1448-77 \\ 2460-77 \\ 2461-77 \\ 2462-77 \\ 2463-77 \\ 2464-77 \\ 2465-77 \\ 2466-77 \\ 2467-77 \\ 2529-77 \\ 2530-77 \\ 2531-77 \\ 2532-77 \\ 2533-77 \\ 2534-77 \\ 2535-77 \\ 2781-77 \\ 3439-77 \\ 3548-77 \\ 3597-77 \\ 439-78 \\ 513-78
}

$\mathrm{IP}^{a}$, urine, France

IP, urine, France

IP, cosmetic, France

IP, pus, France

IP, environment, France

IP, urine, France

IP, urine, France

CDC, blood, United States

CDC, sputum, United States

CDC, abdominal wound, United States

CDC, abscess, United States

CDC, sputum, United States

CDC, abscess, United States

CDC, sputum, United States

CDC, sputum, United States

CDC, ?, United States

CDC, leg wound, United States

CDC, urine, United States

CDC, leg wound, United States

CDC, hand, United States

CDC, hand wound, United States

CDC, blood, United States

CDC, ?, United States

CDC, ?, United States

CDC, water, United States

CDC, blood, United States

CDC, blood, United States

CDC, oral abscess, United States

CDC, urine, United States

CDC, ?, United States

CDC, ?, United States

CDC, ?, United States

CDC, ?, United States

CDC, leg, United States

CDC, ?, United States

CDC, sputum, United States

CDC, sputum, United States

CDC, urine, United States

CDC, ?, United States

CDC, sputum, United States

CDC, kidney, United States

CDC, cyst, United States

CDC, ?, United States

CDC, ?, United States

CDC, ear drainage, United States

CDC, lung, United States

CDC, sputum, United States

CDC, vagina, United States

CDC, cosmetic, United States

CDC, sputum, United States 
TABLE 1.-continued

\begin{tabular}{lll}
\hline \multicolumn{1}{c}{ Strain } & & \\
\hline Escherichia coli & K-12 & University of Washington \\
Hafnia alvei & $4510-72$ & CDC \\
Hafnia alvei & $5632-72$ & CDC \\
& & \\
Klebsiella oxytoca & 13182 & ATCC \\
Klebsiella pneumoniae & 2 & CDC \\
Proteus mirabilis & PR14 & CDC \\
Proteus vulgaris & PR1 & CDC \\
Providencia alcalifaciens & 26240 & CDC \\
Providencia rettgeri & 1163 & CDC \\
Providencia stuartii & $2896-69$ & T. Theodore \\
Salmonella typhi-murium & LT2 & CDC \\
Serratia liquefaciens & $446-68$ & CDC \\
Serratia marcescens & $868-57$ & CDC \\
Serratia rubidaea & $934-72$ & IP, H.H. Mollaret \\
Yersinia enterocolitica & $497-70$ & CDC \\
Yersinia ruckeri & $4535-69$ &
\end{tabular}

${ }^{a}$ IP, Institut Pasteur.

TABLE 2. Biochemical reactions of E. gergoviae

\begin{tabular}{|c|c|c|c|}
\hline Test & Reaction ${ }^{a}$ & \% Positive ${ }^{b}$ & $\begin{array}{l}\text { Reaction of } \\
\text { type strain }\end{array}$ \\
\hline Indole & - & 0 & - \\
\hline Methyl red & $\mathbf{v}$ & 18 & - \\
\hline Voges-Proskauer & + & 99 & + \\
\hline Citrate (Simmons) & + & 98 & + \\
\hline $\mathrm{H}_{2} \mathrm{~S}$ (triple sugar iron) & - & 0 & - \\
\hline Urease & + & 100 & + \\
\hline Phenylalanine deaminase & - & 0 & - \\
\hline Lysine decarboxylase & $\mathbf{v}$ & $80(19)$ & + \\
\hline Arginine dihydrolase & - & 0 & - \\
\hline Ornithine decarboxylase & + & 100 & + \\
\hline Motility & + & 94 & + \\
\hline Gelatin $\left(22^{\circ} \mathrm{C}\right)$ & - & 0 & - \\
\hline KCN (growth) & - & 0 & - \\
\hline Malonate & + & 100 & + \\
\hline D-Glucose (acid) & + & 100 & + \\
\hline D-Glucose (gas) & + & 97 & + \\
\hline \multicolumn{4}{|l|}{ Acid from: } \\
\hline Lactose & $\mathbf{v}$ & $54(29)$ & - \\
\hline Sucrose & + & 100 & + \\
\hline D-Mannitol & + & 100 & + \\
\hline Dulcitol & - & 0 & - \\
\hline Salicin & + & 98 & + \\
\hline Adonitol & - & 0 & - \\
\hline i-Inositol & - & $11(16)$ & - \\
\hline D-Sorbitol & - & 0 & - \\
\hline Sorbose & - & 0 & - \\
\hline L-Arabinose & + & 99 & + \\
\hline Raffinose & + & 100 & + \\
\hline L-Rhamnose & + & 100 & + \\
\hline Maltose & + & 98 & + \\
\hline D-Xylose & + & 99 & + \\
\hline Trehalose & + & 100 & + \\
\hline Cellobiose & + & 98 & + \\
\hline$\alpha-\mathrm{CH}_{3}$-glucoside & - & 1 & - \\
\hline Erythritol & - & 0 & - \\
\hline Mannose & + & 98 & + \\
\hline Melibiose & + & $99(1)$ & + \\
\hline
\end{tabular}


TABLE 2.-continued

\begin{tabular}{lccc}
\hline \multicolumn{1}{c}{ Test } & Reaction & \% Positive & $\begin{array}{c}\text { Reaction of } \\
\text { type strain }\end{array}$ \\
\hline D-Arabitol & + & $96(2)$ & + \\
Glycerol & + & 100 & + \\
ONPG & + & 99 & + \\
Esculin & + & 98 & + \\
Mucate & - & 0 & - \\
Tartrate (Jordan) & + & 100 & + \\
Acetate & + & $98(2)$ & + \\
Lipase (corn oil) & - & 0 & - \\
Deoxyribonuclease $\left(25^{\circ} \mathrm{C}\right)$ & - & 0 & - \\
$\beta$-Xylosidase & - & 0 & - \\
Tetrathionate reductase & - & 0 & + \\
Nitrate to nitrite & + & 98 & - \\
Oxidase & - & 0 & - \\
Yellow pigment & - & 0 & - \\
Lysed by Guinee's & & 0 & \\
Hafnia-specific phage & - & 0 & \\
\hline
\end{tabular}

${ }^{a}$ Reactions obtained within $48 \mathrm{~h}$ at $36 \pm 1^{\circ} \mathrm{C}$ unless specified;,$+ 90 \%$ or more positive;,- 0 to $9.9 \%$ positive; $\mathrm{v}$, variable, 10.0 to $89.9 \%$ positive.

${ }^{b}$ The figures in parentheses are percentages of delayed positive reactions ( 3 to 7 days).

' ONPG, $o$-nitrophenyl- $\beta$-D-galactopyroside.

TABLE 3. Differentiation of Enterobacter species from each other, Klebsiella pneumoniae, and Hafnia alvei (4)

\begin{tabular}{|c|c|c|c|c|c|c|c|}
\hline Test & $\begin{array}{c}E . \\
\text { cloacae }\end{array}$ & $\begin{array}{c}E . \\
\text { aerogenes }\end{array}$ & $\begin{array}{c}E . \\
\text { agglomerans }\end{array}$ & $\begin{array}{c}E . \\
\text { sakazakii }\end{array}$ & $\begin{array}{c}E . \\
\text { gergoviae }\end{array}$ & $\begin{array}{c}K \\
\text { pneumoniae }\end{array}$ & $\begin{array}{c}H . \\
\text { alvei }\end{array}$ \\
\hline Motility & + & + & $\mathrm{v}$ & + & + & - & $v$ \\
\hline Lysine decarboxylase & - & + & - & - & + or $(+)$ & + & + \\
\hline Arginine dihydrolase & + & - & - & + & - & - & $\mathbf{v}$ \\
\hline Ornithine decarboxylase & + & + & - & + & + & - & + \\
\hline Urease & $\mathrm{v}$ & - & $\mathbf{v}$ & - & + & + & - \\
\hline Methyl red & - & - & $\mathbf{v}$ & $\mathbf{v}$ & - & $\mathrm{v}$ & $\mathrm{v}$ \\
\hline Voges-Proskauer & + & + & $\mathrm{v}$ & + & + & + & $\mathrm{v}$ \\
\hline Citrate (Simmons) & + & + & $\mathrm{v}$ & + & + & + & $\mathrm{v}$ \\
\hline KCN (growth) & + & + & $\mathbf{v}$ & + & - & + & + \\
\hline Adonitol & $\mathbf{v}$ & + & $\mathrm{v}$ & - & - & $\mathrm{v}$ & - \\
\hline$i$-Inositol & $\mathbf{v}$ & + & $\mathbf{v}$ & $\mathbf{v}$ & - & + & - \\
\hline D-Sorbitol & + & + & $\mathbf{v}$ & - & - & + & - \\
\hline Mucate & $\mathrm{v}$ & + & $\mathrm{v}$ & - & - & + & - \\
\hline Deoxyribonuclease $25^{\circ} \mathrm{C}$ & - & - & - & + or $(+)$ & - & - & - \\
\hline Yellow pigment & - & - & $\mathbf{v}$ & + & - & - & - \\
\hline $\mathrm{G}+\mathrm{C}(\%)$ & 53 & $54-56$ & $52-58$ & $56-60$ & 60 & $54-56$ & $48-52$ \\
\hline
\end{tabular}

${ }^{a}$ Reactions were obtained at $36 \pm 1{ }^{\circ} \mathrm{C}$ (except for deoxyribonuclease, $25^{\circ} \mathrm{C}$ ). The positive urease activity in E. gergoviae and $K$. pneumoniae is significantly weaker than that seen typically in species of Proteus and Yersinia.,$+ 90 \%$ or more positive within $48 \mathrm{~h} ;(+)$, delayed positive, 3 to 7 days;,- 0 to $9.9 \%$ positive within 48 $\mathrm{h}$; v, variable, 10.0 to $89.9 \%$ positive within $48 \mathrm{~h}$. 
Antibiotic susceptibility. Susceptibility of 25 strains to antibiotics was determined by the disk method of Bauer et al. (1). All strains were resistant to penicillin (Table 4). Most strains were susceptible to the other antibiotics tested. Multiple resistance was found in six strains. A strain isolated in France was resistant to penicillin, ampicillin, and cephalothin. In addition to being resistant to penicillin, one strain isolated in the United States was resistant to cephalothin, and one was resistant to nalidixic acid. Three strains isolated from an outbreak in France (8) were resistant to penicillin, nalidixic acid, and cephalothin. Two of these were also resistant to sulfadiazine, kanamycin, and chloramphenicol.

G+C content and DNA hybridization. Buoyant density ultracentrifugation in $\mathrm{CsCl}$ was used to determine the $\mathrm{G}+\mathrm{C}$ content of DNA from $E$. gergoviae strains 76.01 (604-77) and 11/ 76 (608-77). The buoyant density of both strains was $1.719 \mathrm{~g} / \mathrm{cm}^{3}$, which corresponds to $60 \mathrm{~mol} \%$ $\mathrm{G}+\mathrm{C}$.

${ }^{32} \mathrm{PO}_{4}$-labeled DNA from $E$. gergoviae strain 76.01 was used in DNA hybridization experiments. DNAs from 10 strains of $E$. gergoviae were tested for relatedness with the labeled DNA (Table 5). In $60^{\circ} \mathrm{C}$ reactions, $E$. gorgoviae

TABLE 4. Antibiotic susceptibility profiles for 25 strains of E. gergoviae

\begin{tabular}{crcc}
\hline & \multicolumn{3}{c}{ No. of strains } \\
\cline { 2 - 4 } Antimicrobial agent & $\begin{array}{c}\text { Sus- } \\
\text { cep- } \\
\text { tible }\end{array}$ & $\begin{array}{l}\text { Inter- } \\
\text { medi- } \\
\text { ate }\end{array}$ & $\begin{array}{c}\text { Re- } \\
\text { sist- } \\
\text { ant }\end{array}$ \\
\hline 10 $^{a}$ Colistin $(8,11)^{b}$ & 25 & 0 & 0 \\
30 Nalidixic acid $(13,19)$ & 9 & 12 & 4 \\
250 Sulfadiazine $(12,17)$ & 22 & 1 & 2 \\
10 Gentamicin $(12,13)$ & 25 & 0 & 0 \\
10 Streptomycin $(11,15)$ & 21 & 4 & 0 \\
30 Kanamycin $(13,18)$ & 23 & 0 & 2 \\
30 Tetracycline $(14,19)$ & 24 & 0 & 1 \\
30 Chloramphenicol (12, 18) & 20 & 2 & 3 \\
10 Penicillin $(11,22)$ & 0 & 0 & 25 \\
10 Ampicillin $(11,14)$ & 21 & 3 & 1 \\
100 Carbenicillin $(17,24)$ & 16 & 9 & 0 \\
30 Cephalothin $(14,18)$ & 18 & 3 & 3 \\
\hline
\end{tabular}

${ }^{a}$ The number preceding the name of the antimicrobial is the disk concentration in milligrams.

${ }^{b}$ The first number in parentheses is the largest zone of inhibition (in millimeters) whereby the organism is considered resistant to the antibiotic. The second number in parentheses is the smallest zone of inhibition (in millimeters) whereby the organism is considered susceptible to the antibiotic. Zone sizes between these values are considered to indicate intermediate resistance. For instance, for colistin, with a zone of 8 $\mathrm{mm}$ or less the organism is considered resistant; with a zone of $11 \mathrm{~mm}$ or more, the organism is considered susceptible, and with a zone of 9 to $10 \mathrm{~mm}$, the organism is considered intermediate. strains were at least $75 \%$ related (75 to $97 \%$ ). The thermal stability of DNA duplexes formed in homologous $E$. gergoviae 76.01 reactions at $60^{\circ} \mathrm{C}$ was approximately $94^{\circ} \mathrm{C}$. The average thermal stability of heterologous $E$. gergoviae DNA duplexes was only $1^{\circ} \mathrm{C}$ lower than that of homologous duplexes. Thus, almost no divergence has occurred in DNA sequences held in common between strains of $E$. gergoviae. The $60^{\circ} \mathrm{C}$ incubation temperature is close to optimal for DNA reassociation. When DNA is hydridized at $75^{\circ} \mathrm{C}$, only closely related DNA sequences can reassociate. On the basis of the very low percentage of divergence of related $E$. gergoviae DNA in $60^{\circ} \mathrm{C}$ reactions, one would predict that almost all of these duplexes would be stable at $75^{\circ} \mathrm{C}$. This is indeed the case (Table 5). Thus, biochemical homogeneity in $E$. gergoviae is reflected by a high level of genetic relatedness in strains from France, Africa, and several states in the United States.

$E$. gergoviae is most similar biochemically to the genus Enterobacter. DNA relatedness of $E$. gergoviae to members of Enterobacteriaceae is highest with $E$. aerogenes, $E$. cloacae, two of the hybridization groups in $E$. agglomerans, and klebsiellae (35 to $40 \%$ ). E. gergoviae is 7 to $15 \%$ related to Hafnia, Yersinia, and protei, and 20 to $30 \%$ related to other genera.

$E$. gergoviae is distinct both biochemically and genetically from the presently described species of Enterobacteriaceae. The G+C value of $60 \mathrm{~mol} \%$ is compatible with findings for species of Serratia, Klebsiella, and Enterobacter. $E$. gergoviae is closest genetically to Enterobacter and Klebsiella. Biochemically it is closest to Enterobacter on the basis of its motility and positive reaction for ornithine decarboxylase.

The name Enterobacter gergoviae sp. nov. is proposed for this organism. The specific epithet gergoviae indicates that the type strain was isolated from samples taken during a urinary infection outbreak in Clermont-Ferrand University Hospital near Gergovie Highland in France. The suggested pronunciation is ger (rhymes with her) gó vee $\bar{e}$.

Strain CIP 76.01 (= ATCC $33028=$ CDC 60477 ) is the type strain of the species.

The clinical significance of $E$. gergoviae is not yet known. Some 80 sporadic isolates have been identified in our laboratories since 1976, and the organism has been implicated in a nosocomial outbreak of urinary tract disease (8). This already relatively large number of isolates will undoubtedly increase as laboratories become familiar with the characteristics of $E$. gergoviae.

\section{REPRINT REQUESTS}

Address reprint requests to: Don J. Brenner, Ph. D., Enteric Section, 1-B311, Center for Disease Control, Atlanta, GA 30333. 
TABLE 5. DNA relatedness of E. gergoviae 76.01 to E. gergoviae strains and members of Enterobacteriaceae

\begin{tabular}{|c|c|c|c|c|}
\hline \multirow{2}{*}{ Source of unlabeled DNA } & & \multicolumn{3}{|c|}{$\mathrm{RBR}^{a}$} \\
\hline & & $60^{\circ} \mathrm{C}$ & $75^{\circ} \mathrm{C}$ & $\$ \mathrm{D}^{h}, 60^{\circ} \mathrm{C}$ \\
\hline Enterobacter gergoviae & $76.01(604-77)$ & 100 & 100 & 0.0 \\
\hline E. gergoviae & $76.02(605-77)$ & 86 & 94 & \\
\hline E. gergoviae & $1 / 77(606-77)$ & 77 & 86 & 0.1 \\
\hline E. gergoviae & $12 / 76(607-77)$ & 75 & 82 & 0.6 \\
\hline E. gergoviae & $11 / 76(608-77)$ & 77 & 92 & \\
\hline E. gergoviae & $20 / 75(610-77)$ & 97 & 100 & 0.7 \\
\hline E. gergoviae & $569-77$ & 97 & 99 & \\
\hline E. gergoviae & $2656-76$ & 76 & 81 & 1.5 \\
\hline E. gergoviae & $2787-76$ & 88 & 92 & \\
\hline$E$. gergoviae & $2863-76$ & 88 & 86 & \\
\hline E. gergoviae & $3782-76$ & 89 & 93 & 2.1 \\
\hline Enterobacter aerogenes & $1627-66$ & 40 & 15 & \\
\hline Enterobacter cloacae & $1347-71$ & 39 & 15 & 12.6 \\
\hline Enterobacter sakazakii & $4562-70$ & 28 & 9 & \\
\hline Klebsiella pneumoniae & 2 & 38 & 16 & 12.8 \\
\hline Klebsiella oxytoca & 13182 & 36 & 19 & \\
\hline Enterobacter agglomerans & $2780-70$ & 26 & & \\
\hline E. agglomerans & $1429-71$ & 23 & & \\
\hline E. agglomerans & $3482-71$ & 17 & 3 & \\
\hline E. agglomerans & 4388-71 & 40 & 13 & \\
\hline E. agglomerans & $5378-71$ & 40 & 12 & \\
\hline E. agglomerans & $1645-71$ & 22 & & \\
\hline H. alvei & $4510-72$ & 14 & & \\
\hline H. alvei & $5632-72$ & 13 & & \\
\hline Serratia marcescens & $868-57$ & 19 & 11 & 13.8 \\
\hline S. liquefaciens & $446-68$ & 24 & & \\
\hline S. rubidaea & $934-72$ & 23 & 3 & \\
\hline E. coli & $\mathrm{K}-12$ & 33 & 9 & 14.0 \\
\hline Salmonella typhi-murium & LT2 & 30 & 9 & 14.7 \\
\hline Edwardsiella tarda & $3592-64$ & 20 & & \\
\hline Yersinia enterocolitica & $497-70$ & 15 & & \\
\hline Yersinia ruckeri & $4535-69$ & 15 & 1 & \\
\hline Proteus mirabilis & PR14 & 7 & & \\
\hline Proteus vulgaris & PR1 & 10 & 0 & \\
\hline Providencia rettgeri & 1163 & 10 & 0 & \\
\hline Providencia alcalifaciens & 26240 & 7 & 0 & \\
\hline Providencia stuartii & $2896-69$ & 9 & & \\
\hline
\end{tabular}

${ }^{a}$ RBR, Relative binding ratio; a convenient way to express percent DNA relatedness. RBR $=\%$ heterologous DNA reaction $/ \%$ homologous DNA reaction $\times 100$.

${ }^{b} \% \mathrm{D}$, Percentage of divergence; calculated on the assumption that each $1^{\circ} \mathrm{C}$ in thermal stability of a DNA duplex is caused by $1 \%$ of unpaired bases within that duplex (2). For example, consider organisms A and B that are $50 \%$ related. An A-A duplex has a mean thermal stability of $90^{\circ} \mathrm{C}$, and an A-B duplex has a mean thermal stability of $80^{\circ} \mathrm{C}$. The $\mathrm{D}$ in related DNA is $10 \%$.

\section{LTTERATURE CITED}

1. Bauer, A. W., W. M. M. Kirby, J. C. Sherris, and M. Turk. 1966. Antibiotic susceptibility testing by a standardized single disc method. Am. J. Clin. Pathol. 45: 493-496.

2. Bonner, T. I., D. J. Brenner, B. R. Neufeld, and R. J. Britten. 1973. Reduction in the rate of DNA reassociation by sequence divergence. J. Mol. Biol. 81:123-135.

3. Brenner, D. J., J. J. Farmer III, G. R. Fanning, A. G. Steigerwalt, P. Klykken, H. G. Wathen, F. W. Hickman, and W. H. Ewing. 1978. Deoxyribonucleic acid relatedness in species of Proteus and Providencia. Int. J. Syst. Bacteriol. 28:269-282.

4. Brenner, D. J., J. J. Farmer III, F. W. Hickman, M. A. Asbury, and A. G. Steigerwalt. 1977. Taxonomic and nomenclature changes in Enterobacteriaceae. Cen- ter for Disease Control Publication, Atlanta, Ga.

5. Edwards, P. R., and W. H. Ewing. 1972. Identification of Enterobacteriaceae, 3rd ed. Burgess Publishing Co., Minneapolis.

6. Mandel, M., C. L. Schildkraut, and J. Marmur. 1968. Use of $\mathrm{CsCl}$ density gradient analysis for determining the guanine plus cytosine content of DNA. Methods Enzymol. 12B:184-195.

7. Richard, C., B. Brisou, and J. Lioult. 1972. Etude taxonomique de Levinea. Nouveau genre de la famille des entérobactéries. Ann. Inst. Pasteur (Paris) 123A: 341-347.

8. Richard, C., B. Joly, J. Sirot, G. H. Stoleru, and M. Popoff. 1976. Etude de souches de Enterobacter appartenant à un groupe particulier proche de $E$. aerogenes. Ann. Inst. Pasteur (Paris) 127 A:545-548. 